\title{
МАСОМЕТРИЧНА ХАРАКТЕРИСТИКА КАМЕР СЕРЦЯ ПРИ ПОСТРЕЗЕКЦІЙНІЙ ПОРТАЛЬНІЙ ГІПЕРТЕНЗІї
}

\author{
๑Н. М. Гданська, Л. В. Татарчук, М. С. Гнатюк, С. О. Коноваленко, Р. І. Цицюра \\ Тернопільський національний медичний університет імені І. Я. Горбачевського МОз України
}

РЕзЮМЕ. Видалення значних об'ємів паренхіми печінки нерідко призводить до пострезекційної портальної гіпертензії, яка ускладнюється кровотечами з варикозно розширених вен стравохода і шлунка, прямої кишки, асцитом, спленомегалією, вторинним гіперспленізмом, паренхіматозною жовтяницею, портосистемною енцефалопатією, поліорганною недостатністю.

Мета - встановити особливості масометричних змін камер серця в умовах пострезекційної портальної гіпертензії.

Матеріал і методи. Масометрично досліджені камери серця 34 лабораторних статевозрілих білих щурівсамців, які були поділені на 2 групи. 1-а група нараховувала 15 інтактних практично здорових експериментальних тварин, 2-а - 19 щурів зі змодельованою пострезекційною портальною гіпертензією. Евтаназію щурів здійснювали кровопусканням в умовах тіопенталового наркозу. Проводили окреме зважування частин серцевого м'яза, при якому враховували: чисту масу серця, абсолютну масу лівого і правого шлуночків, шлуночковий індекс, індекс Фултона, масу лівого і правого передсердь, відсотки мас шлуночків і передсердь, індекс передсердь, індекс передсердно-шлуночковий правий і лівий. Частини серця досліджували гістологічно. Масометричні параметри камер серця обробляли статистично.

Результати. Встановлено, що резекція лівої та правої бокових часток печінки у щурів призводила до розвитку пострезекційної портальної гіпертензії, яка характеризувалася розширенням та венозним повнокров'ям ворітної печінкової вени, брижових вен, вен стравоходу та шлунка, передньої черевної стінки, спленомегалією, асцитом. Масометричні параметри камер серця при цьому змінювалися. Так, чиста маса серця в умовах змодельованого експерименту збільшилася на 19,5 \%, абсолютна маса лівого шлуночка - на 24,1 \%. правого - на 11,4 \% ( $p<0,001)$, лівого передсердя - на $21,0 \%$, правого - на 8,4 \% ( $<<0,01)$. Шлуночковий індекс при цьому зменшився на 10,3\%, індекс передсердно-шлуночковий лівий - на 3,7 \%, правий - на 2,5 \%, індекс Фултона зріс на 17,7 \%, індекс передсердь - на 9,8 \%, серцевий індекс - на 11,6 \%, що свідчило при диспропорційність гіпертрофії камер серця в умовах пострезекційної портальної гіпертензії і підтверджувалося відсотками їх масометричних параметрів.

Висновки. Проведеним масометричним вивченням особливостей ремоделювання камер серця в умовах пострезекційної портальної гіпертензії встановлено нерівномірне, диспропорційне збільшення мас камер серця з домінуючою гіпертрофією лівого шлуночка та лівого передсердя.

КлючОВІ СлОВА: камери серця; масометрія; пострезекційна портальна гіпертензія.

Вступ. Відомо, що зміни гемодинаміки у великому та малому колах кровообігу, в системі ворітної печінкової вени призводять до структурнофункціональних змін тих або інших відділів серця. Видалення значних об'ємів паренхіми печінки сьогодні нерідко виконується у сучасних хірургічних клініках і може призводити до пострезекційної портальної гіпертензії $[2,5,6]$. Остання ускладнюється кровотечами з варикозно розширених вен стравоходу і шлунка, прямої кишки, асцитом, спленомегалією, вторинним гіперспленізмом, паренхіматозною жовтяницею, портосистемною енцефалопатією, поліорганною недостатністю [5]. В умовах портальної гіпертензії насамперед уражаються органи, венозний відтік від яких здійснюється через ворітну печінкову вену, яка відіграє важливу роль у підтриманні та регуляції гомеостазу. Гіпертензія та тривале венозне повнокров'я у венах органів ворітної печінкової вени індукують гіпоксію, порушення перфузії вказаних органів, що призводить до їх ураження та дисфункції, розвиток якої в органах може призвести до поліорганної недо- статності [2, 5]. Кількісні морфологічні методи, до яких належить масометрія, широко застосовуються для вивчення закономірностей ремоделювання органів та при різних патологічних станах [10, 11]. В той же час особливості масометричного ремоделювання камер серця при пострезекційній портальній гіпертензії повністю не досліджені.

Мета - встановити особливості масометричних змін камер серця в умовах пострезекційної портальної гіпертензії.

Матеріал і методи дослідження. Масометрично досліджені камери серця 34 лабораторних статевозрілих білих щурів-самців, які були поділені на 2 групи. 1-а група нараховувала 15 інтактних практично здорових експериментальних тварин, 2-а - 19 щурів зі змодельованою пострезекційною портальною гіпертензією [2]. Евтаназію лабораторних статевозрілих білих щурів-самців здійснювали кровопусканням в умовах тіопенталового наркозу. Розкривали грудну клітку, виймали серце, яке розрізали за методом Г. Г. Автандилова [1]. Проводили окреме зважування частин серцевого 
Огляди літератури, оригінальні дослідження, поглядн на м'яза, при якому враховували такі морфометричні параметри: чиста маса серця (ЧМС) - маса серцевого м'яза без клапанів, великих судин, субепікардіальної жирової клітковини, абсолютна маса лівого (МЛШ) і правого (МПШ) шлуночків - маса шлуночка з пропорційною його масі міжшлуночковою перегородкою, шлуночковий індекс (Шا) - відношення МПШ до МЛШ, індекс Фултона (ІФ) - відношення маси лівого шлуночка разом з міжшлуночковою перегородкою до маси правого шлуночка, серцевий індекс (Cl) - відношення чистої маси серця до маси тварини, маса лівого (МЛП) і правого (МПП) передсердь, відсотки мас шлуночків (\% лШ, \% ПШ) і передсердь (\% ЛП, \% ПП), індекс передсердь (ІПр) відношення маси лівого передсердя до маси правого, індекс передсердно-шлуночковий лівий (ІПрШЛ) - відношення маси лівого передсердя до маси лівого шлуночка, індекс передсердно-шлуночковий правий (ІПрШП) - відношення маси правого передсердя до маси правого шлуночка $[1,10,11]$. Брали шматочки з частин серця для гістологічного дослідження [3]. Отримані масометричні параметри камер серця обробляли статистично. Обробку результатів виконано у відділі системних статистичних досліджень Тернопільського національного медичного університету імені І. Я. Горбачевського МО3 України в програмному пакеті STATISTICA (Stat. Soft Inc., США). Різницю між порівнюваними морфометричними параметрами визначали за критеріями Стьюдента та Манна - Уїтні $[1,4]$. Необхідно зазначити, що здійснені експериментальні дослідження та евтаназію дослідних тварин виконували із дотриманням «Загальних етичних принципів експериментів на тваринах", ухвалених Першим національним конгресом з біоетики (Київ, облему, випадок з практики, короткі повідомлення 2001) та відповідно до «Європейської конвенції про захист хребетних тварин, що використовуються в дослідних та інших наукових цілях» [9].

Результати й обговорення. У результаті проведених досліджень встановлено, що резекція лівої та правої бокових часток печінки призводила до розвитку пострезекційної портальної гіпертензії, яка характеризувалася розширенням та венозним повнокров'ям ворітної печінкової вени, брижових вен, вен стравоходу та шлунка, передньої черевної стінки, спленомегалією, асцитом [2, 5]. Отримані масометричні параметри камер серця лабораторних статевозрілих білих щурів-самців представлені у таблиці 1. Усестороннім аналізом показаних у названій таблиці кількісних морфологічних параметрів встановлено, що більшість їх при пострезекційній портальній гіпертензії виражено змінювалася. Так, чиста маса серця в умовах змодельованого експерименту збільшилася 3 $(778,3 \pm 8,1)$ мг до $(930,3 \pm 7,5)$ мг. Наведені масометричні параметри статистично достовірно відрізнялися між собою ( $<<0,001)$. При цьому останній кількісний морфологічний параметр перевищував попередній на 19,5\%.

Абсолютна маса лівого шлуночка при пострезекційній портальній гіпертензії зросла з (484,6士 $4,5)$ мг до $(601,2 \pm 5,4)$ мг, тобто на $24,1 \%$. Варто зазначити, що між наведеними масометричними параметрами лівого шлуночка виявлена виражена статистично достовірна різниця ( $p<0,001)$. А6солютна маса правого шлуночка в умовах досліджуваного експерименту змінювалася аналогічно. Так, у лабораторних статевозрілих білих щурів-самців контрольної групи вказаний кількісний морфологічний показник дорівнював $(212,6 \pm$

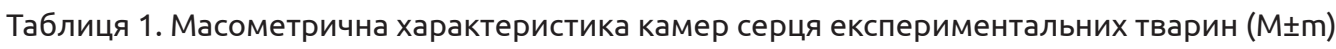

\begin{tabular}{|c|c|c|}
\hline \multirow{2}{*}{ Показник } & \multicolumn{2}{|c|}{ Група спостереження } \\
\hline & 1 & 2 \\
\hline ЧМС, Мг & $778,2 \pm 8,1$ & $930,3 \pm 7,5 * * *$ \\
\hline МЛШ, мг & $484,6 \pm 4,5$ & $601,2 \pm 5,4 * * *$ \\
\hline МПШ, мг & $212,6 \pm 2,1$ & $236,3 \pm 2,1 * * *$ \\
\hline МЛП, мг & $39,50 \pm 0,42$ & $47,80 \pm 0,45^{* * *}$ \\
\hline МПП, мг & $41,5 \pm 0,39$ & $45,00 \pm 0,42 * *$ \\
\hline Шا & $0,438 \pm 0,004$ & $0,393 \pm 0,003 * * *$ \\
\hline $\mathrm{Cl}$ & $0,00430 \pm 0,00004$ & $0,00480 \pm 0,00005 * * *$ \\
\hline $1 \Phi$ & $3,10 \pm 0,03$ & $3,65 \pm 0,03 * * *$ \\
\hline ІПр & $0,951 \pm 0,01$ & $1,044 \pm 0,011$ ** \\
\hline ІПршЛ & $0,0810 \pm 0,0007$ & $0,078 \pm 0,0006^{*}$ \\
\hline ІПрШП & $0,195 \pm 0,002$ & $0,190 \pm 0,002 *$ \\
\hline \% лш & $62,3 \pm 0,4$ & $64,3 \pm 0.4 * *$ \\
\hline \% ПШ & $27,30 \pm 0,27$ & $25,40 \pm 0,21 * *$ \\
\hline \% лП & $5,10 \pm 0,05$ & $5,10 \pm 0,03$ \\
\hline \% ПП & $5,30 \pm 0,05$ & $5,00 \pm 0,03 * *$ \\
\hline
\end{tabular}

Примітка. *- ${ }^{*}<0,05 ; * *-\mathrm{P}<0,01 ; * * *-\mathrm{P}<0,001$ 
Огляди літератури, оригінальні дослідження, погляд на проблему, випадок з практики, короткі повідомлення $2,1)$ мг, а при пострезекційній портальній гіпертензії - $(236,3 \pm 2,1)$ мг. При цьому останній масометричний параметр з високим ступенем статистично достовірної різниці $(p<0,001)$ перевищував попередній на $11,4 \%$.

Маса передсердь в умовах змодельованої пострезекційної портальної гіпертензії також змінювалася. В даних експериментальних умовах маса лівого передсердя збільшилася з $(39,50 \pm$ $0,42)$ мг до $(47,80 \pm 0,45)$ мг. Між наведеними масометричними параметрами встановлена статистично достовірна $(p<0,01)$ різниця. При цьому останній кількісний морфологічний показник перевищував попередній на 21,0 \%. Маса правого передсердя у лабораторних статевозрілих білих шурів-самців контрольної групи дорівнювала $(41,50 \pm 0,39)$ мг, а у експериментальних тварин 3 пострезекційною портальною гіпертензією - $(45,00 \pm 0,45)$ мг. Останній кількісний морфологічний показник з вираженою статистично достовірною різницею $(p<0,001)$ перевищував попередній на 8,4 \%.

Шлуночковий індекс, що відображав відношення між абсолютними масами правого та лівого шлуночків серця у даних експериментальних умовах з вираженою статистично достовірною різницею $(p<0,001)$ зменшився з $(0,438 \pm 0,004)$ до $(0,393 \pm 0,003)$, тобто на $10,3 \%$. Виявлене зниження шлуночкового індексу свідчило про домінуючу гіпертрофію лівого шлуночка порівняно з правим. Індекс Фултона при пострезекційній портальній гіпертрофії статистично достовірно $(p<0,001)$ зріс з $(3,10 \pm 0,03)$ до $(3,65 \pm 0,03)$, тобто на $17,7 \%$. Встановлене виражене зростання індексу Фултона підтверджувало переважаючу гіпертрофію лівого шлуночка, порівняно з правим, в умовах змодельованого експерименту.

Необхідно зазначити, що при експериментальній пострезекційній портальній гіпертензії змінювався також індекс передсердь, який відображав відношення між масами лівого та правого передсердь. При цьому у лабораторних статевозрілих білих щурів-самців контрольної групи вказаний кількісний морфологічний показник дорівнював $(0,951 \pm 0,001)$, а при пострезекційній портальній гіпертензії - $(1,044 \pm 0,011)$. Наведені кількісні морфологічні показники статистично достовірно $(p<0,001)$ відрізнялися між собою. При цьому останній морфометричний показник перевищував попередній на 9,8 \%, вказуючи на домінуючу гіпертрофію лівого передсердя. Серцевий індекс у досліджуваних експериментальних умовах збільшився на $11,6 \%(p<0,001)$, вказуючи на виражену гіпертрофію камер. Індекс передсердно-шлуночковий лівий при змодельованій пострезекційній портальній гіпертензії зменшився на 3,7 \%, правий - на $2,5 \%(p<0,05)$. Зміни наведених індексів свідчили при диспропорційність гіпертрофії камер серця в умовах пострезекційної портальної гіпертензії і підтверджувалися відсотками їх масометричних параметрів. Відомо, що дисбаланс між масометричними параметрами камер серця може призводити до його дисфункції $[7,10,11]$.

Відомо, що патогенез гіпертрофії камер серця складний і досить багатогранний, що значною мірою ускладнює своєчасну ї̈ діагностику. Ріст артеріального судинного опору в малому колі кровообігу при різних хронічних ураженнях легень призводить до посиленої роботи, тобто гіперфункції правого шлуночка і його гіпертрофії [10, 11], а домінуюча гіперфункція та гіпертрофія лівого шлуночка найчастіше виникає при гіпертензії у великому колі кровообігу $[8,12]$. Отримані в результаті проведеного дослідження дані свідчать, що для руху венозної крові у портальній системі через печінку потрібна також посилена робота лівого шлуночка. Відомо, що спочатку при посиленій роботі виникає гіпертрофія гіперфункціонуючого шлуночка, тобто компенсаторний процес на навантаження, а надалі розвиваються патологічна гіпертрофія та інтерстиціальний фіброз, що виявлялося у камерах серця при гістологічному дослідженні. Ці процеси призводять до збільшення жорсткості шлуночка, підвищення кінцево-діастолічного тиску, діастолічної дисфункції та розвитку серцевої недостатності $[7,10,12]$.

Висновки. Проведеним масометричним вивченням особливостей ремоделювання камер серця в умовах пострезекційної портальної гіпертензії встановлено нерівномірне диспропорціональне збільшення мас камер серця з домінуючою гіпертрофією лівого шлуночка та лівого передсердя.

Перспективи подальших досліджень. Всестороннє і детальне дослідження масометричних параметрів камер серця дозволить покращити діагностику, профілактику та корекцію особливостей ремоделювання частин серцевого м'яза при різних гемодинамічних розладах. 


\section{ЛІТЕРАТУРА}

1. Автандилов Г. Г. Основы количественной патологической анатомии / Г. Г. Автандилов . - М. : Медицина, 2002. -240 c.

2. Гнатюк М. С. Порушення всмоктувальної функції тонкої кишки при пострезекційній портальній гіпертензії / М. С. Гнатюк, Л. В. Татарчук // Вісник наукових досліджень. - 2018. - № 2. - С.115-120.

3. Горальський Л. П. Основи гістологічної техніки і морфофункціональні методи досліджень у нормі та при патології / Л. П. Горальський, В. Т. Хомич, О. І. Кононський. - Житомир : Полісся, 2011. - 288 с.

4. Гржибовский А. И. Сравнение количественных данных двух парных выборок с использованием программного обеспечения Statistica и SPSS: параметрические и непараметрические критерии / А. И. Гржибовский, О. В. Иванов, М. А. Горбатова // Наука и здравоохранение. - 2016. - № №. - С. 5-25.

5. Дзигал О. Ф. Формування полісиндромної недостатності хворих на цироз печінки з портальною гіпертензією / О. Ф. Дзигал // Вісник наукових досліджень. 2017. - № 2. - С. 88-92.

6. Хірургічне лікування вогнищевого ураження печінки: аналіз результатів та перспективи / О. І. Дронов, С. В. Земсков, Ю. П. Бакунець, П. П. Бакунець // Клінічна хірургія. - 2016. - № 1. - С. 28-31.

\section{REFERENCES}

1. Avtadnilov, G.G. (2002). Osnovy kolichestvennoy patologicheskoy anatomii [Basis of Quantitative Pathological Anatomy]. M. : Medicyna [in Russian].

2. Hnatjuk, M.S., \& Tatarchuk, L.V. (2018). Porushennia vsmoktuvalnoi funktsii tonkoi kyshky pry postrezektsijnii portalnoy hipertenziy [Violation of the absorption function of the small intestine at postresection portal hypertension]. Visnyk naukovykh doslidzhen - Bulletin of Scientific Research, 2, 115-120 [in Ukrainian].

3. Horalskyi, L.P., Khomych, V.T., \& Kononskyy, O.I. (2011). Osnovy histolohichnoyi tekhniky i morfofunktsionalni metody doslidzhen u normi ta pry patolohiy [Fundamentals of histological technique and morphofunctional methods of research in norma and in pathology]. Zhytomyr: Polissia [in Ukrainian].

4. Grzhibovsky, A.I. , Ivanov, O.V., \& Gorbatova, M.A. (2016). Sravnennia kolichestvennych dannych dvuch parnych vyborok s ispolzovanijm programnogo obespechenia Statistica i SPSS; parametricheskie and neparametricheski criterii [Comparison of Quantitative Data of Two Paired Samples Using Statistica and SPSS Software: Parametric and Nonparametric Criteria]. Nauka i zdravokhranenie-Science and Health, 3, 5-25 [in Ukrainian].

5. Dzyhal, O.F. (2017). Formuvannya polisyndromnoyi nedostatnosti khvorykh na tsyroz pechinky z portalnoyu hipertenziyeyu [Formation of polysyndromic insufficiency of patients with liver cirrhosis with portal hypertension]. Visnyk naukovykh doslidzhen. - Bulletin of Scientific Research, 2, 88-92 [in Ukrainian].

6. Dronov, O.I., Zemskov, S.V., \& Bakunets, P.P.(2016). Khirurhichne likuvannya vohnyshchevoho urazhennya pechinky: analiz rezultativ ta perspektyvy [Surgical treatment of focal liver disease: analysis of results and prospects]. Klinichna khirurhiya. - Clinical Surgery, 1, 28-31 [in Ukrainian].
7. Коблалава ж. Д. Непропорционально высокая масса миокарда левого желудочка у больных с артериальной гипертонией. Клинические ассоциации и особенности ремоделирования / Ж. Д. Коблалава, Ю. В. Котовская, А. Ф. Сафарова // Кардиология. - 2008. - Т. 48, № 11. - С. 19-28.

8. Королюк О. Гіпертрофія лівого щлуночка при артеріальній гіпертензії: сучасні уявлення та діагностико-лікувальний підхід // Здоров'я України. - 2018. № 23. - С. 4-6.

9. Резніков О. Г. Загальні етичні принципи експериментів на тваринах / О. Г. Резніков // Ендокринологія. - 2003. - № 8. - С. 142-145.

10. Слабий О. Б. Масометрична характеристика камер компенсованого та декомпенсованого легеневого серця / О. Б. Слабий, Л. В. Татарчук, М. С. Гнатюк // Вісник наукових досліджень. - 2016. - № 2. - С. 76-78.

11. Татарчук Л. В. Морфометричний аналіз ремоделювання камер серця після пульмонектомії // Здобутки клінічної та експериментальної медицини. 2011. - № 2 (15). - С. 124-125.

12. Lovic D. How to estimate left ventricular hypertrophy in hypertensive patients / D. Lovic, S. Erdirie, A. Catakoglu // Anadolu kardiyal derg. - 2014. - 14 (4). - P. 389-395.

7. Koblalava, Zh..D., Kotovskaia, Yu.V., \& Cafarova, A.F. (2008). Neproportsionalno vysokaya massa miokarda levogo zheludochka u bolnykh s arterialnoy gipertoniyey. Klinicheskiye assotsiatsii i osobennosti remodelirovaniya [Disproportionaly high left ventricular myocardial mass in patients with hypertension. Clinical associations and features of remodeling]. Cardiologia - Cardiology, 48 (11), 19 28 [in Russian].

8. Korolyuk, O. (2018). Hipertrofiya livoho shchlunochka pry arterialniy hipertenzii: suchasni uyavlenya ta diahnostyko-likuvalnyy pidkhid [Hypertrophy of the left ventricle in arterial hypertension: modern imaginations and diagnostic and therapeutic approach]. Zdorovia Ukrayiny. Health of Ukraine, 23, 4-6 [in Ukrainian].

9. Reznikov, O.G. (2003). Zahalni etychni pryntsypy eksperymentiv na tvarynakh [General ethical principles of experiments on animals]. Endokrynolohiia-Endocrinology, 8, 1, 142-145 [in Ukrainian].

10. Slabyy, O.B., Tatarchuk, L.V., \& Hnatyuk, M.S. (2016). Masometrychna kharakterystyka kamer kompensovanoho ta dekompensovanoho lehenevoho sertsya [Massometric characteristics of chambers of compensated and decompensated cor pulmonale]. Visnyk naukovykh doslidzhen - Bulletin of Scientific Research, 2,76-78 [in Ukrainian].

11. Tatarchuk, L.V. (2011). Morfometrychnyi analiz remodeliuvannia kamer sertsia pislia pulmonektomii [Morphometric analysis of the heart chamber remodeling after pulmonectomy]. Zdobutky klinichnoi ta eksperymentalnoi medytsyny - Achievements of Clinical and Experimental Medicine, 2 (15), 124-126 [in Ukrainian].

12. Lovic, D., Erdirie, S., \& Catakoglu, A. (2014). How to estimate left ventricular hypertrophy in hypertensive patients. Anadolu Kardiyal Derg, 14 (4), 389-395. 

PORTAL HYPERTENSION

\author{
@N. N. Gdanska, L. V. Tatarchuk, M. S. Gnatyuk, S. A. Konovalenko, R. I. Tsytsiura \\ I. Horbachevsky Ternopil National Medical University
}

SUMMARY. Removal of significant volumes of the liver parenchyma often leads to postresection portal hypertension, which is complicated by bleeding from varicose veins of the esophagus and stomach, rectum, ascites, splenomegaly, secondary hypersplenism, parenchymal jaundice, multiorgan failure.

The aim - to establish the features of massometric changes of the heart chambers in the conditions of postresection portal hypertension

Material and Methods. The chambers of the heart of 34 laboratory mature white male rats, which were divided into 2 groups, were massometrically examined. The 1 group consisted of 15 intact practically healthy experimental animals, 2 - 19 rats with simulated postresection portal hypertension. Euthanasia of rats was performed by bloodletting under thiopental anesthesia. A separate weighing of parts of the heart muscle was performed, which took into account: heart mass, absolute left and right ventricular mass, ventricular index, Fulton's index, left and right atrial mass, percentages of ventricular and atrial masses, atrial index, right atrioventricular index and left. Parts of the heart were examined histologically. Massometric parameters of the heart chambers were processed statistically.

Results. It was found that resection of the left and right lateral lobes of the liver in rats led to the development of postresection portal hypertension, which was characterized by dilation and venous plethora of the portal hepatic vein, mesenteric veins, esophageal and gastric veins, anterior abdominal wall, splenomegaly, ascites. The massometric parameters of the heart chambers changed. Thus, the weight of the heart in the simulated experiment increased by $19.5 \%$, the absolute mass of the left ventricle - by $24.1 \%$. right - by $11.4 \%(p<0.001)$, left atrium - by $21.0 \%$, right - by $8.4 \%$ ( $p<0.01$ ). The ventricular index decreased by $10.3 \%$, the left atrioventricular index - by $3.7 \%$, right - by $2.5 \%$, the Fulton index increased by $17.7 \%$. atrial index - by $9.8 \%$, cardiac index - by $11.6 \%$, which indicated the disproportion of the hypertrophy of the chambers of the heart in conditions of postresection portal hypertension and was confirmed by the percentage of their massometric parameters.

Conclusions. A massometric study of the features of remodeling of the heart chambers in the conditions of postresection portal hypertension revealed an uneven, disproportional increase in the mass of the heart chambers with dominant hypertrophy of the left ventricle and left atrium.

KEY WORDS: heart chambers; massometry; postresection portal hypertension. 